
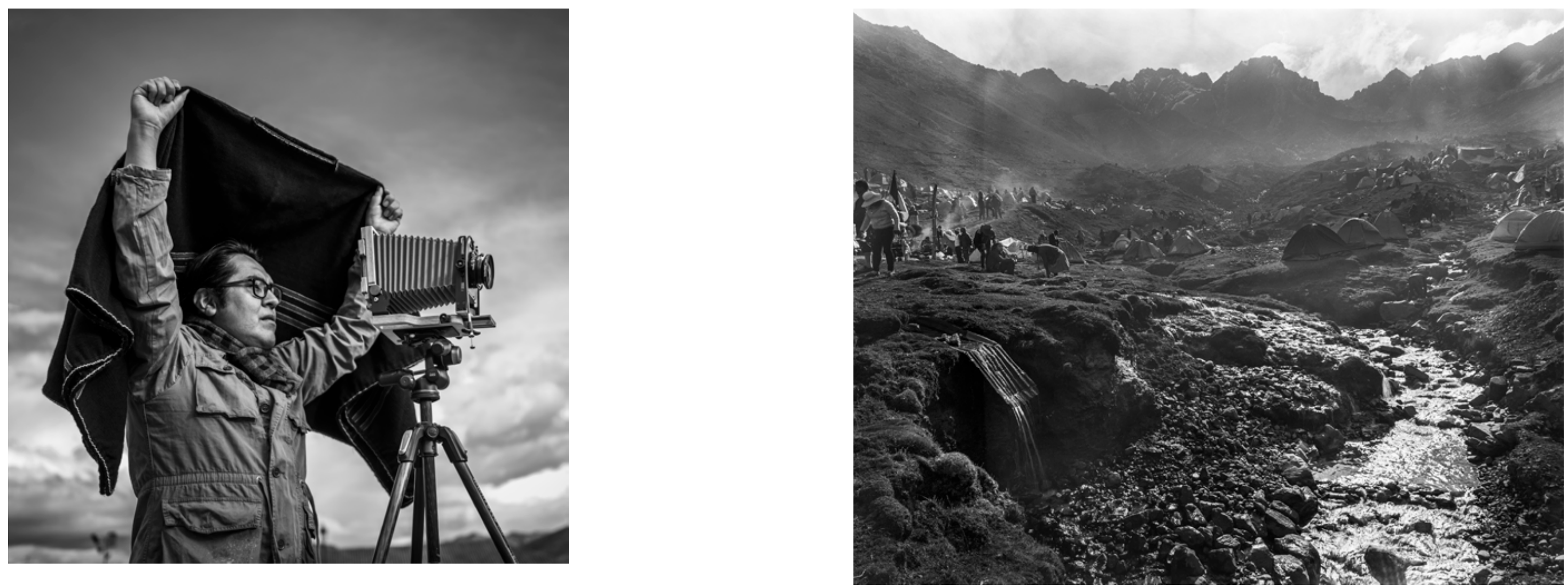

\title{
UN SOÑADOR NTREPIDO EN LOS ANDES
}

\section{EL QOYLLUR RIT'I EN LAS PLACAS DE JERO GONZALES}

LA COSMOVISIÓN ESTÁ PRESENTE EN EL LENGUAJE, EN LOS SONIDOS Y EN EL PAISAJE. POR ELO, JERO GONZALES HA RECORRIDO EL NEVADO AUSANGATE DURANTE LA FESTIVIDAD DEL SEÑOR DE QOYLLUR RIT'I, EN EL CUSCO, ACOMPANADO DE UNA CAMARA DE GRAN FORMATO $\left(4 \times 5^{\prime \prime}\right)$ PARA MOSTRAR LOS ROSTROS DE DIVERSOS PUNTOS DEL PERÚ. ¿CÓMO SE LOGRA RECORRER UN MISMO CAMINO DE FE Y ESPERANZA A TRAVÉS DE LA FOTOGRAFÍA?

\section{Eluis Cáceres álvarez} https://orcid.org/0000-0002-1738-5483 Periodista y docente de la Universidad Peruana de Ciencias Aplicadas - UPC pcculcac@upc.edu.pe

amina pausado. Carga un trípode y una cámara de placas en su hombro derecho. Más una mochila donde guarda los lentes, el fotómetro, Contempla muchachos que le bailan a la montaña y a los espíritus protectores-; como también, de otros serios e incrédulos. "Ellos son nosotros mismos en distintos estados" dice y sigue su camino. Se llama Jero Gonzales (Cusco, 1982), fotógrafo errante en la festividad religiosa del Qoyllur rit'i que se desarolla en el distrito cusqueño de Ocongate, en a provincia de Quispicanchi, quien registra los rostros de los viajeros. Así, se sorprende con la revelación de los trajes, de las cruces, de los ríos, pero, sobre personajes que ha encontrado durante 30 años a lo largo de esa ruta.
Durante dos años después de terminar el colegio, a finales de los noventa, Jero estuvo en un limbo. Había decidido no estudiar una carrera profesional convencional. Se inclinó por la computación porque lo veía como un complemento para cualquier carrera que estudiara luego. "En el contexto donde yo vivo elegimos las carreras para estudiar por el tema económico. Muchas veces prevalece eso. Tiene más peso que algo que te quste", sostiene. Sin embargo, no dejó sus pasos por la música ni como danzante. No es hasta el 2012 que tuvo la oportunidad de trabajar en el distrito de Ocongate donde descubrió que la fotografía sería un camino de vida. Comenzó a ver imágenes impresas en blanco y negro de los Talleres de Fotografía Social (TAFOS). Luego, asistió una exposición de Martín Chambi en el 


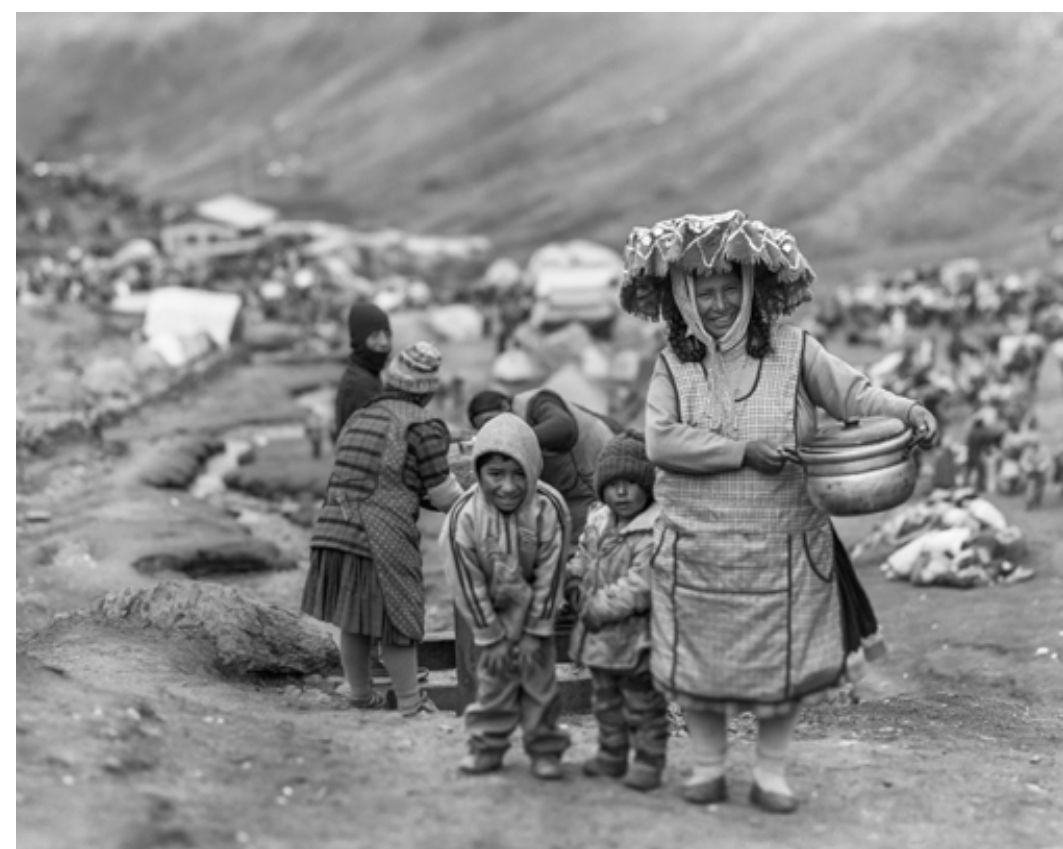

Cusco y recorrió la festividad del Qoyllur rit'i con una cámara. Desde entonces, solo pensaba en udiar. "Uno por su cuenta puede aprender en 10 años y lograr trabajos increíbles, pero cuando se estudia tres años con experimentación nos ahorra tiempo en construir propuestas fotográficas", opina.

El lingüista Mario Montalbetti dice que el Perú tiene una tradición artística importante en poesía y fotografía. Jero insiste en que los nuevos fotógrafos deberían de conocer esas fuentes. "Nuestro país está aprendiendo a valorar más el trabajo fotográfico", recalca. Sus influencias son por etapas. Él admira a Martín Chambi porque fue un aventurero como Ansel Adams y Robert Frank. También a Fernando La Rosa, Billy Hare, Javier Silva Meinel; quienes nos han ayudado a pensar nuestro país. "El legado a través de sus ojos, es experimental y sensorial", dice. Asimismo, defiende el uso del quechua, su lengua materna, que aprendió al vivir con sus abuelos. Por ende, los proyectos que formaliza son un homenaje a ellos; como también, a sus memorias de la niñez, para demostrar que el idioma nos hace comprender un mundo. "Es la principal justificación para acercarme al modo, quiere contribuir en el crecimiento de su comunidad.

Es devoto del Señor de Qoyllur Rit'i. Por eso, explica a otros de qué trata su proyecto: Puriq significa el caminante o el que camina. Masiy significa compañero. "Puriq masiy puede ser el compañero de camino desde un tema de dice Jero quien tiene com tiene como ejem plo a Ansel Adams. "Su trabajo está relacionado al paisaje y eso a mí me inspira. De alguna manera, yo quiero seguir sus pasos". El proyecto Puriq Masiy simboliza para Jero que la calma tiene mucho más para "revelarnos". Se trata de " "yo relaciono la luz a la fotografía, a la cámara pero también a un sentido de esperanza. La revelación es a las placas, pero también cuando uno intenta encontrar la verdad, visibilizando estos aspectos de cultura, de tradición y de fe a través del camino".

Le hechiza la suma de la técnica y el esfuerzo. Ir al lugar sin cámara a escuchar, a oler, a ver con el corazón porque la creatividad llega con los estímulos. Ese es su cable a tierra. El blanco y negro es parte de su lenguaje, pero no se limita. La mayor parte de su trabajo apela a la exploración, la sensorialidad y la experiencia.

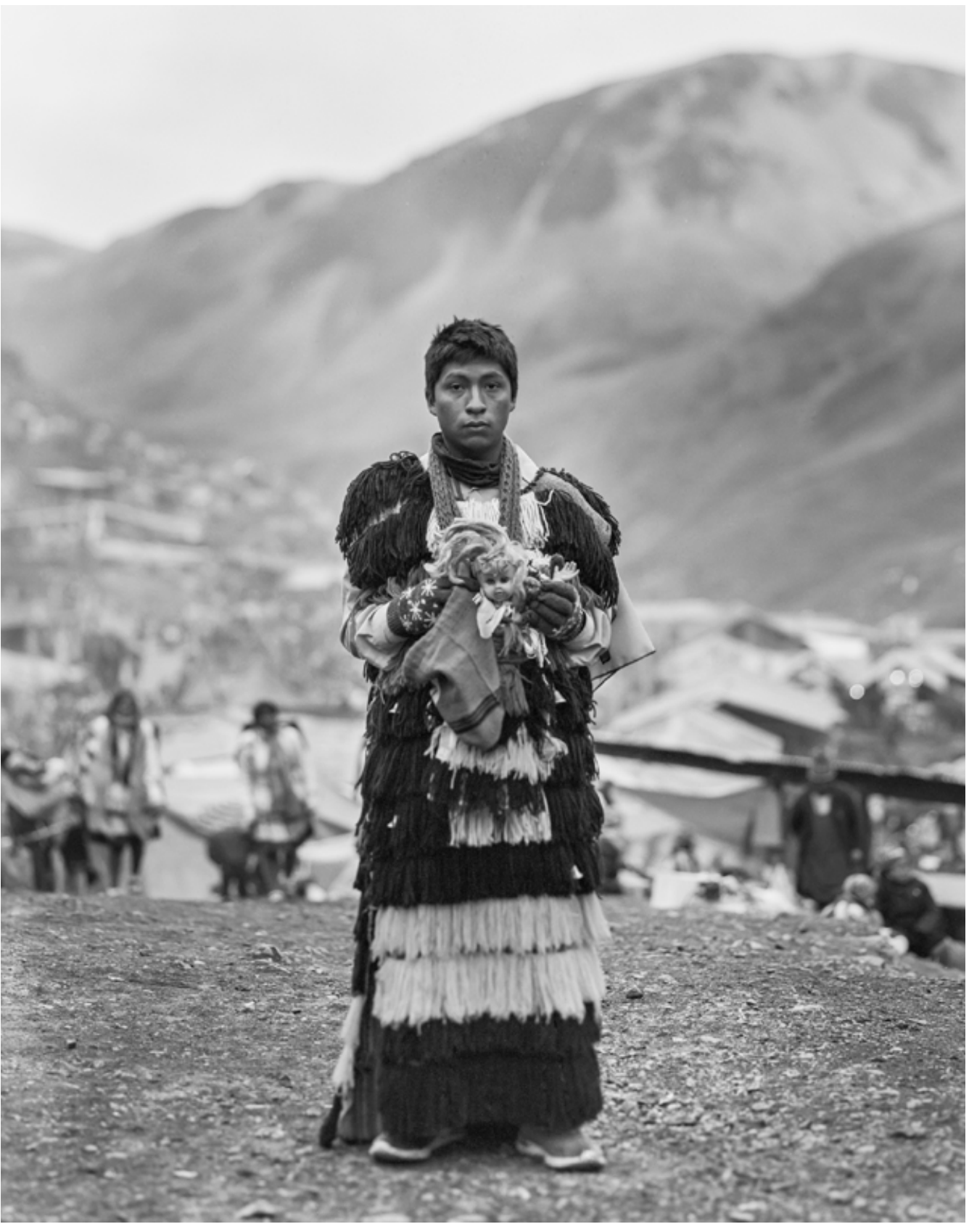


Le encanta que sus imágenes gocen de personalidad y que respiren. Si hay desconfianza, se nota en el retrato. Salvando las distancias, iría a las fiestas e invitaría a personas que no conoce a que posen. Él llama "retratos intrépidos" a esos ensayos que le brindan la oportunidad de acercarse. Comienza de cero porque "si quieres retratar a una persona que conoces, ya es gratuito". O fácil. Lo principal para Jero es que a los retratados no se les note la tensión, que no se sientan forzados. Piensa en la reciprocidad. Le entregan su tiempo, su imagen y sus ilusiones.

Esos "retratos intrépidos" fueron hechos en Chinchero, en Paucartambo, en Puno y en otras comunidades de camino a la festividad del Qoyllur rit'i, el peregrinaje ritual al pie del nevado Ausangate a $4700 \mathrm{msnm}$ y a temperaturas por debajo de los $0{ }^{\circ} \mathrm{C}$, dominando el equipo usaría la cámara de gran formato, justamente, como una preparación para Puriq Masiy porque tenía que resolverlo en un solo viaje y en tres días. Lo que hacía era prueba y error en otras

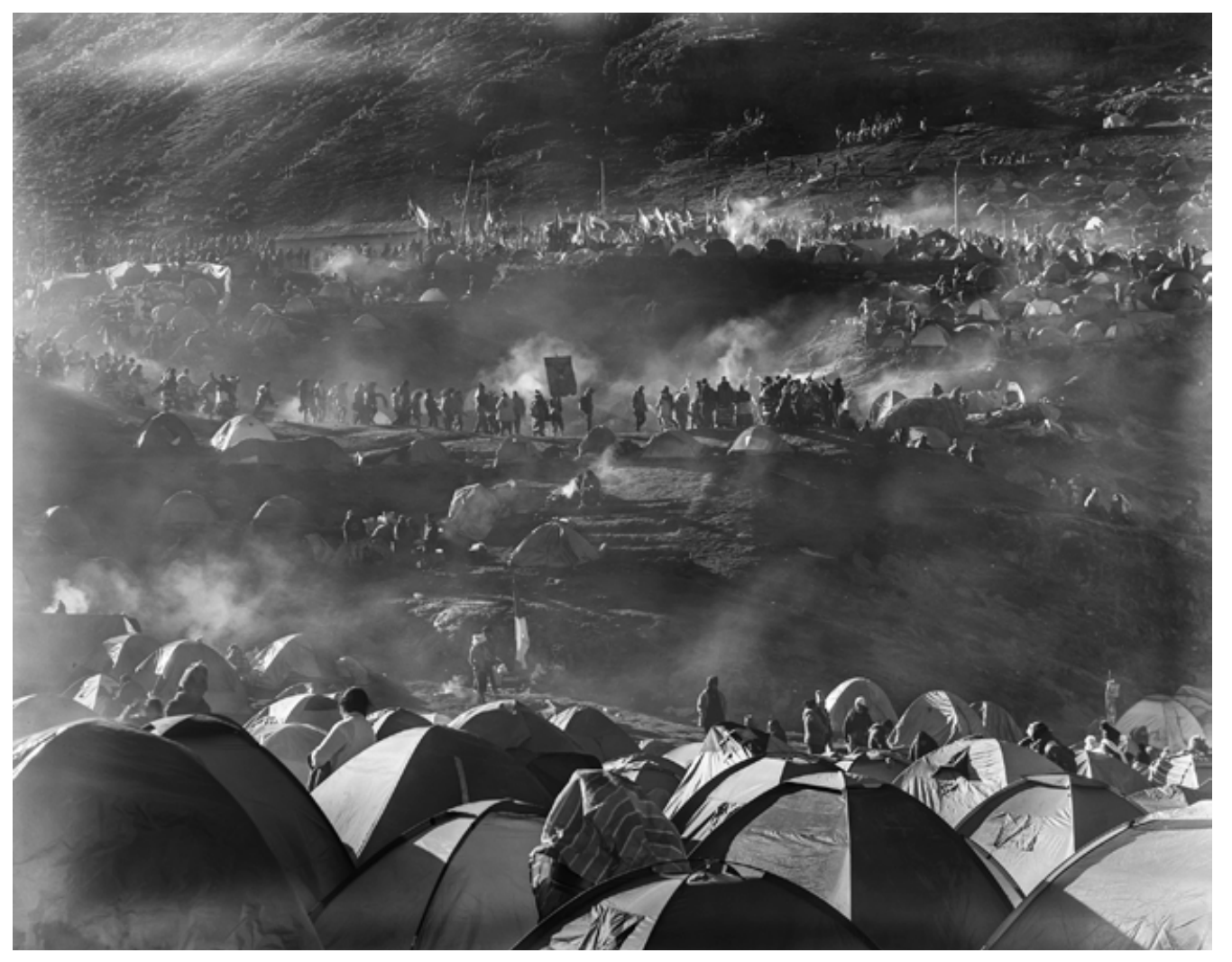

celebraciones. "Estos retratos fueron la mejor excusa para ir a las fiestas patronales del Cusco excusa para ir a las fiestas patronales del Cusco la vida", confiesa y ríe porque puede ser muy hablador con amigos, pero con persona desconocidas le resulta difícil, por su carácter.

No todas las imágenes se leen de la misma manera, dependen de la experiencia de la cultura visual. El fotógrafo debe preguntar sobre qué quiere mostrar y responder qué quiere decir. Su expertise dura más allá del acto fotográfico. Para Jero, tienes que plantar una imagen con una cámara de placas, te va a demorar, así que aprovecho ese tiempo para conocer a la persona", dice que quienes posan están contentos porque está dispuesto a sacarles una fotografía para perdurar su memoria.

"Antes de la toma tú puedes ver a los ojos al retratado y el retratado te puede ver a los ojos. Con la cámara de placas, tú te pones I ela encima para enfocar, colocas el chasis para el tripode. Enfocar. Encuadrar. "Cuando creas hacer la toma final y miras de frente al retratado. Me gusta porque creas un vínculo efímero que se queda atrapado en la imagen. Ese momento es mágico". Es un proceso que le gusta contar: "El primer minuto en que una persona está frente a una cámara, está ansioso. En el minuto dos se le va pasando. Habla algo con el fotógrafo en el minuto tres y asume que va a demorarse un poco más. Se relaja. En el minuto cinco, seis o siete hacemos la foto".

A pesar del trabajo duro en la montaña Jero también llevó consigo una impresora portátil y una cámara digital. Primero, registró en placas y luego imprimía las digitales mientras guardaba los equipos. Un gesto noble de su parte porque muchas veces el fotógrafo no se compromete y se demora en devolver las imágenes que obtiene. "Encuentro un paralelo entre la vida misma y esos ocho kilómetros de recorrido donde te vas conociendo, te acercas a ellos y ellos te aceptan a ti", dice.

Sus temas son reflexivos, de cómo el ser humano aprende a vivir con lo que le toca. Para Jero, no tenemos nada que envidiar a otros países. Exportamos buena factura. Es cuestión de valorar lo que tenemos. A través de sus ojos, él quiere: "Humanizar a las personas, no exotizarlas. Humanizar nuestra cultura". Solo necesita tiempo para investigar a profundidad, para reflexionar, para conceptualizar: "Es como si fueses una radio que va sincronizando frecuencias $u$ ondas. Todos estos estímulos sensoriales te dirán algo, o sentirás algo, a partir de ahí podrás construir alguna propuesta, o un discurso frente al tema, la situación o lo que tú quieras decir". $\bullet$ 